\title{
EVALUATION OF Helicobacter pylory COLONIZATION BY SEROLOGIC TEST (IgG) AND DYSPEPSIA IN VOLUNTEERS FROM THE COUNTRYSIDE OF MONTE NEGRO, IN THE BRAZILIAN WESTERN AMAZON REGION
}

\author{
Rafael Bernardon RIBEIRO(1), Herlon Saraiva MARTINS(3), Vera Aparecida dos SANTOS(2), Marcelo EL KHOURI(1), Leandro Savoy DUARTE(1), \\ Marcelo Nascimento BURATTINI(2), Quirino CORDEIRO(1), Luiz Marcelo Aranha CAMARGO(4) \& Carlos Eduardo Pereira CORBETT(1)
}

\begin{abstract}
SUMMARY
The present study intended to analyze the seroprevalence of Helicobacter pylori, IgG, and its relation to dyspepsia in a population from the western Amazon region. During the "Projeto Bandeira Científica", a University of São Paulo Medical School program, in Monte Negro's rural areas, state of Rondônia, 266 blood samples were collected from volunteers. The material was tested for IgG antibodies anti-Helicobacter pylori by ELISA method and the participants were also interviewed on dyspepsia, hygiene and social aspects. Participants aged between five and 81 years old (34 years on average), 149 (56\%) were female and 117 (44\%) male. We found $210(78.9 \%)$ positive, $50(18.8 \%)$ negative and six $(2.3 \%)$ undetermined samples. Dyspeptic complaints were found in 226 cases $(85.2 \%)$. There was no statistical association between dyspepsia and positive serology for H. pylori. We concluded that the seroprevalence in all age categories is similar to results found in other studies conducted in developing countries, including those from Brazil. On the other hand, the seroprevalence found in Monte Negro was higher than that reported in developed countries. As expected, there was a progressive increase in the positivity for H. pylori in older age groups.
\end{abstract}

KEYWORDS: Seroprevalence; Helicobacter pylori; Dyspepsia; Western Amazon.

\section{INTRODUCTION}

Dyspepsia is one of the most common complains in primary care medicine. It accounts for about $5 \%$ of the general practitioner attendance, $40 \%$ of the gastroenterological consults and may affect, even sporadically, up to $25 \%$ of the population ${ }^{11,15}$. Does Helicobacter pylori play an important role in dyspeptic symptoms? Could Helicobacter pylori treatment eradicate this symptom? According to guidelines, the 'test and treat' strategy, which consists of treating positive patients without alarming signs before an endoscopy, is the most beneficial intervention and could be considered to be standard practice ${ }^{5,6,10,11}$.

The infection rates in the world are estimated to be around 50\%, and humans are considered the main reservoir ${ }^{2,4}$. The transmission routes are oral-oral and oral-fecal, which justifies the differences in seroprevalence seen between developed and undeveloped countries and its association with improvements of sanitary conditions, ${ }^{1,9,16,17}$.

For peptic ulcers, a clear association between the infection by Helicobacter pylori and gastric or duodenal lesions has been accepted ${ }^{18}$. Nowadays, there is evidence of a bacterial role in non-ulcers dyspepsia in infected patients. The difference between treated and untreated individuals, regarding symptom control, has been shown to be discrete ${ }^{6,10,12,19}$. However, the general agreement for the management of young patients without alarming signs, and in populations where the prevalence of $H$. pylori is above $15 \%$, is to test (urea breath or stool antigen) and treat ${ }^{8,13,18}$. Recent systematic reviews showed a small but statistically significant effect in $H$. pylori eradication in these cases, since this infection is associated with duodenal and gastric ulcer diseases, atrophic gastritis and gastric cancer ${ }^{8,11}$. The infection rates among symptomatic individuals are higher, suggesting that more virulent agents could be implicated, as those expressing the CagA antigen ${ }^{4,12}$.

The present study was conducted during the "Bandeira Científica da Faculdade de Medicina da USP ${ }^{7}-2000$ edition", with the aim of studying the profile of $H$. pylori and dyspepsia in the Western Amazon population ${ }^{5}$.

The site of study, Monte Negro, state of Rondônia, is located $250 \mathrm{~km}$ south from the state capital, Porto Velho, and had 12,086 inhabitants at the time, $60 \%$ living in rural zones (Fig. 1). The climate is of the equatorial Amazon rainforest type (warm and humid) ${ }^{3}$.

\section{MATERIAL AND METHODS}

After informed consent, blood samples were collected by the 37 participating students, during assistance intervals. The patients were

(1) Laboratório de Patologia das Moléstias Infecciosas, São Paulo, SP, Brasil.

(2) Seção de Imunologia da Divisão de Laboratório Central, Hospital das Clínicas da Faculdade de Medicina da USP, São Paulo, SP, Brasil.

(3) Hospital das Clínicas/FMUSP, Hospital Universitário/USP, São Paulo, SP, Brasil.

(4) Núcleo Avançado de Pesquisas de Monte Negro (RO)/Instituto de Ciências Biomédicas da USP.

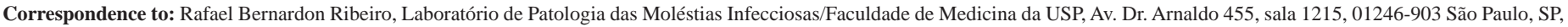
Brasil. Phone: +55.11.3061-7426. E-mail: rafael@usp.br 


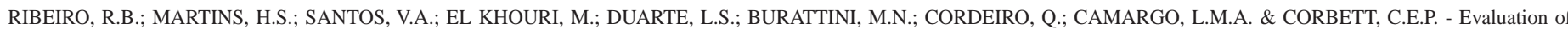
Helicobacter pylori colonization by serologic test (IgG) and dyspepsia in volunteers from the countryside of Monte Negro, in the Brazilian Western Amazon region. Rev. Inst. Med. Trop. Sao Paulo, 52(4): 203-6, 2010.
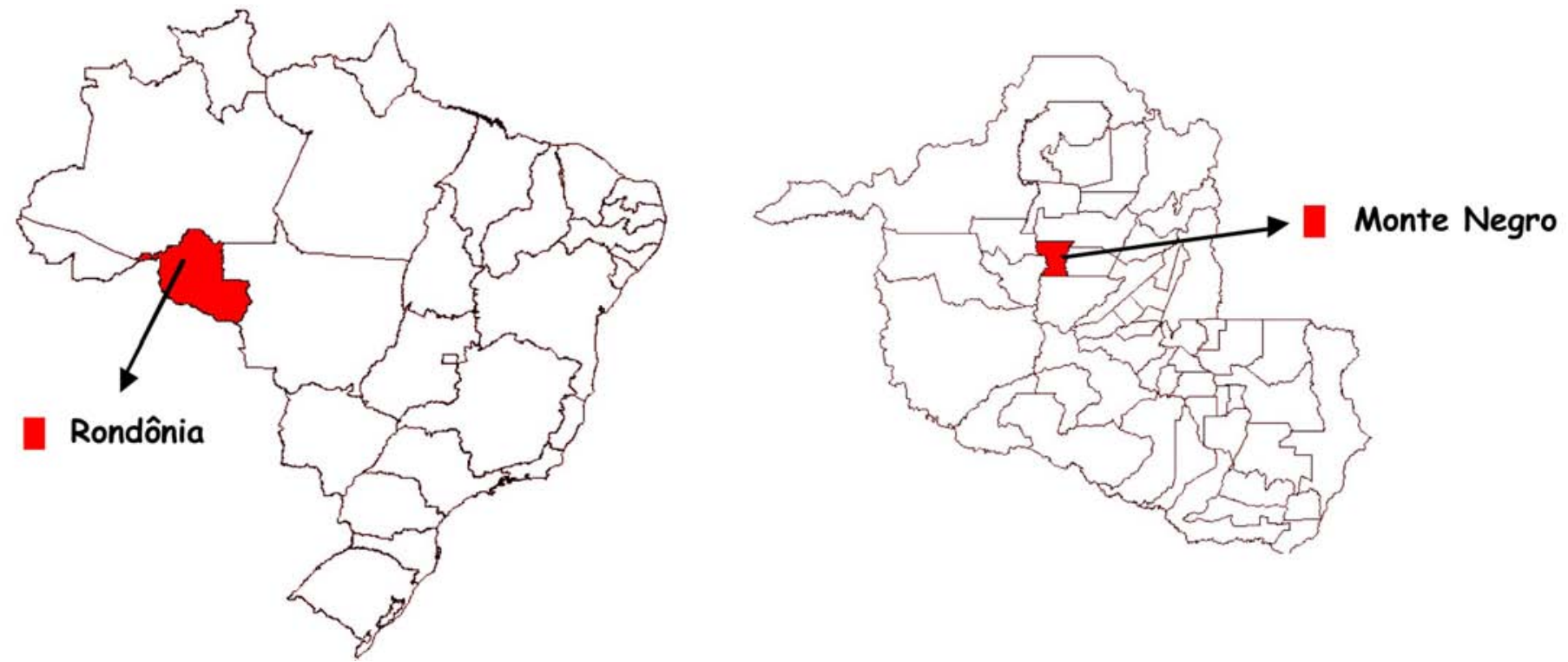

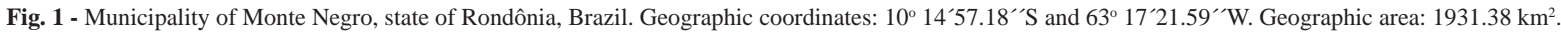

selected by communitarian health agents and invited to join the research. Blood samples were collected from 266 individuals using Vacutainer ${ }^{\circledR}$ tubes. Each patient also answered a questionnaire to evaluate dyspeptic symptoms (pyrosis, heartburn, epigastric pain, postprandial fullness).

The biological samples were transported to Sao Paulo in "dry ice" for cooling and conservation. The material was tested for IgG antibodies against Helicobacter pylori by Cobas $^{\circledR}$ Core II, Anti-H. pylori ELISA, $\mathrm{ROCHE}^{\circledR}$, at the Immunology Service of Central Laboratory Division (DLC-HCFMUSP). The reference values for positive tests were $6.6 \mathrm{U} / \mathrm{mL}$ or higher and between 5.4 and $6.6 \mathrm{U} / \mathrm{mL}$ for undetermined. Dyspeptic symptoms were compared between the groups with positive and negative serology for $H$. pylori using chi-square test performed by the SPSS ${ }^{\circledast}$ (Statistical Package for Social Sciences version 14.0/2005) for Windows ${ }^{\circledR}$.

\section{RESULTS}

The patients were aged between five and 81 years old, a mean of 34 years old; of whom 149 (56\%) were female (Table 1). Regarding education, $20.3 \%$ were analphabets and $77.6 \%$ had only incomplete basic alphabetization. Just $38 \%$ were born in State of Rondônia and the average time living there was 12.8 years. The families were constituted of an average of 4.5 members and the familial monthly income was 1,154.5 American dollars at that time. About hygienic issues, 90.4\% of the patients did not have a treated water supply.

Table 1

Demographic features (number of patients: 266)

\begin{tabular}{cccccccc}
\hline \multicolumn{2}{c}{ Sex } & \multicolumn{5}{c}{ Ages distribution (years old) } \\
\hline Male & Female & $0-10$ & $11-20$ & $21-30$ & $31-40$ & $41-50$ & $>50$ \\
\hline 117 & 149 & $12.3 \%$ & $17.7 \%$ & $16.2 \%$ & $16.9 \%$ & $12.3 \%$ & $24.6 \%$ \\
$(44 \%)$ & $(56 \%)$ & & & & & & \\
\hline
\end{tabular}

Positive tests were found in $210(78.9 \%)$, negative in $50(18.8 \%)$ and undetermined in six $(2.3 \%)$ cases. The last group was re-tested, using the same sample and three remained undetermined, one became positive and two negative. For data analysis, we considered these six cases as undetermined. The numbers and percentages of positive cases for each age group are shown in Table 2.

Table 2

Test results for each age group (262 individuals who informed age)

\begin{tabular}{lll}
\hline $\begin{array}{l}\text { Age group } \\
\text { (years old): }\end{array}$ & $\begin{array}{l}\text { Total of patients } \\
\text { in the group }\end{array}$ & $\begin{array}{l}\text { Positive tests for } \\
\boldsymbol{H} \text {. pylori }\end{array}$ \\
\hline $0-10$ & 32 & 17 cases $(54.8 \%$ of 32$)$ \\
$11-20$ & 46 & 35 cases $(77.8 \%$ of 46$)$ \\
$21-30$ & 42 & 32 cases $(76.2 \%$ of 42$)$ \\
$31-40$ & 45 & 33 cases $(73 \%$ of 45$)$ \\
$41-50$ & 32 & 27 cases $(84.3 \%$ of 32$)$ \\
$>50$ & 65 & 56 cases $(86.15 \%$ of 65$)$ \\
\hline
\end{tabular}

Based on 265 questionnaire answers, dyspeptic symptoms were a common finding, being divided into: heartburn 141 cases $(53.2 \%)$, epigastric pain 166 cases $(62.6 \%)$ and postprandial fullness 136 cases $(51.3 \%)$. In $85 \%$ of the cases there was at least one of them.

There was no statistical association between dyspeptic symptoms and positive serology $\left(\chi^{2}=2.33, p=0.12\right)$.

\section{CONCLUSION}

The rates of infection in the studied area are comparable with neighbor countries and other Amazon Brazilian states ${ }^{3,4,15}$. These rates were also similar to other developing countries and higher than those 


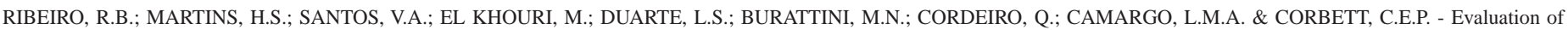

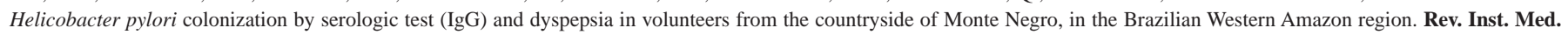
Trop. Sao Paulo, 52(4): 203-6, 2010.

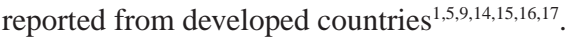

The results show that there was no association between dyspeptic complaints and positive serology for $H$. pylori. This was a particular finding and maybe due to the fact that the rates of dyspepsia were over estimated.

The rates of infection rise with age, which is commonly described in the literature. About $50 \%$ of the sample had a positive test before the age of 10 , which could indicate interfamilial promiscuity and lack of hygiene, or simply to be a hyperendemic region. After 20 years old, $80 \%$ of adults had positive tests (Fig. 2).

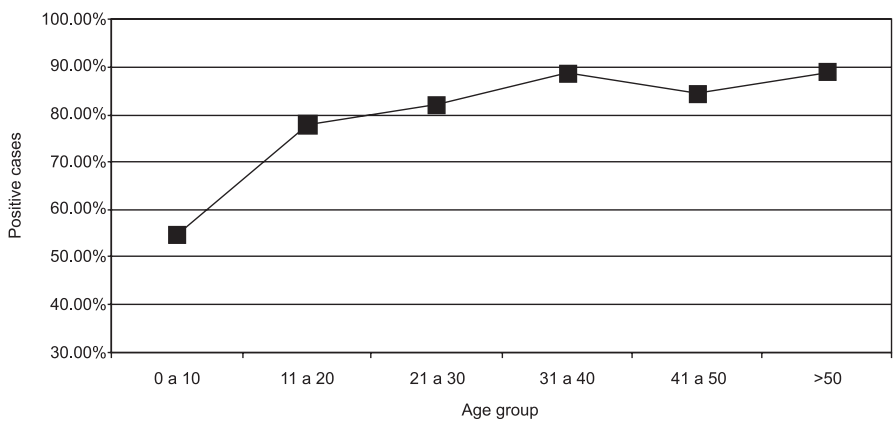

Fig. 2 - Serology results and age groups.

Since there is evidence of the association between $H$. pylori and gastric/duodenal ulcers and gastric cancer, high seroprevalence rates could indicate high levels of untreated infection, which may be considered a public health problem. Therefore more research is needed to better evaluate the endemic pattern of this region and to propose proper control measures.

\section{RESUMO}

\section{Avaliação da colonização por Helicobacter pylori através de teste sorológico (IgG) e de dispepsia em voluntários da população rural de Monte Negro (RO), região da Amazônia ocidental}

Este trabalho tem por objetivo analisar a soroprevalência do Helicobacter pylori, IgG, em população rural da Amazônia, e sua correlação com queixa dispéptica. No Projeto Bandeira Científica da FMUSP, em Monte Negro - RO, foram coletadas 266 amostras sangüíneas nos assentamentos rurais do município. Foram pesquisados anticorpos da classe $\mathrm{IgG}$ dirigidos contra Helicobacter pylori pelo método ELISA e aplicados questionários sobre dispepsia, aspectos sociais e epidemiológicos. Os pacientes tinham idades entre cinco e 81 anos (média de 34 anos); 149 (56\%) do sexo feminino e 117 (44\%) do sexo masculino. Foram encontradas 210 (78.9\%) amostras positivas, 50 negativas $(18.8 \%)$ e seis indeterminadas $(2.3 \%)$. A queixa de dispepsia foi encontrada em 226 casos (85.2\%). Não houve associação significativa entre os sintomas dispépticos e a soro positividade para $H$. pylori. Concluímos que a soro prevalência para todas as faixas etárias é comparável com os resultados de outros estudos realizados em países em desenvolvimento, e maior que aquela encontrada nos países desenvolvidos. Houve aumento progressivo da positividade com a idade, como citado na literatura.

\section{ACKNOWLEDGEMENTS}

"USP/Reitoria e Pró-reitoria de Cultura e Extensão" and "Faculdade de Medicina"; "Secretaria de Estado da Saúde"/Prof. Dr. José da Silva Guedes; "Superintendência do Hospital das Clínicas da FMUSP”/Dr. José D’Elia Filho; Dra. Flávia Trench and Dr. Sérgio Bassano. All the students participating of the study were as follows: Ana Cláudia Lopes Calças, André Russowsky Brunoni, Cristiane Emi Tsuboi, Sebastian Naschold Geiger, Silvio Eitatsu Senhara, Ciro Eduardo de Souza, Caio Vinicius de Meira G. Simioni, Cristiane Yoko Fukuda, Eliane Aparecida Rosseto, Ernesto Dallaverde Jr., Fábio de Barros, Fábio Mitsuo Murate, Karina Takesaki Miyaji, Luciana Takeuchi Branco, Paulo Eduardo Machado Filho, Matheus Schmidt Gomes de Oliveira, Otávio Prado Alabarse, Pedro Luiz Guimarães Costa, André Nathan Costa, Janos Giurycza, Bruno de Carvalho Fantini, Luiz Fernando Ferraz da Silva, Marco Antonio Silva dos Santos, Patrícia Yuko Hiraki, Paulo Henrique Nascimento Harada, Ricardo Vessoni Perez, Wilson Sampaio de Almeida, Beatriz Gonçalves Miron, Andreas Stravogianis, Francisco Donato Jr., Lana Leini Okada, André Curcio.

\section{REFERENCES}

1. Almeida Cunha RP, Alves FP, Rocha AM, Rocha GA, Camargo LM, Nogueira PO, et al. Prevalence and risk factors associated with Helicobacter pylori infection in native populations from Brazilian Western Amazon. Trans R Soc Trop Med Hyg. 2003;97:382-6.

2. Brown, LM. Helicobacter pylori: epidemiology and routes of transmission. Epidemiol Rev. 2000;22:283-97.

3. Camargo LM, Moura MM, Engracia V, Pagotto RC, Basano SA, Da Silva LH, et al. A rural community in a Brazilian Western Amazonian Region: some demographic and epidemiological patterns. Mem Inst Oswaldo Cruz. 2002;97:193-5.

4. Cartágenes VD, Martins LC, Carneiro LM, Barile KA, Corvelo TC, et al. Helicobacter pylori em crianças e associação de cepas CagA na transmissão mãe-filho na Amazônia brasileira. Rev Soc Bras Med Trop. 2009;42:298-302.

5. Chehter EZ, Maximiano FL, Nogueira LF, Blandi FA, Burdelis RE, Xavier MF et al. Clinical and epidemiological characteristics of Helicobacter pylori infection among patients in specialty outpatient clinics at Faculdade de Medicina ABC. Sao Paulo Med J. 2007;125:300-1.

6. Gisbert JP, Boixeda D, Martín De Argila C, García Plaba A. Helicobacter pylori y dispepsia no ulcerosa: una asignatura pendiente. Rev Esp Enferm Dig. 1998;90:441-53

7. Goldbaum M, Ribeiro RB, Curcio A, Franco LL, Cardoso MN, Machado Filho PE et al. Prevalência de toxoplasmose, leishmaniose, doença de Chagas e enteroparasitoses em voluntários da população de Cajati, Estado de São Paulo, 1998. Rev Med (FMUSP). 1999;78:498-507.

8. Graham DY, Rugge M. Clinical practice: diagnosis and evaluation of dyspepsia. J Clin Gastroenterol. 2010;44:167-72.

9. Herbarth O, Krumbiegel P, Fritz GJ, Richter M, Schlink U, Müller DM, et al. Helicobacter pylori prevalences and risk factors among school beginners in a German urban center and its rural country. Environ Health Perspect. 2001;109:573-7.

10. Lewis JD. Population screening and treatment of Helicobacter pylori Gastroenterology. 2000;119:1795-7.

11. Moayyedi P, Soo S, Deeks J, Delaney B, Harris A, Innes M, et al. Eradication of Helicobacter pylori for non-ulcer dyspepsia. Cochrane Database of Systematic Reviews 2006. Issue 3, Art. No. CD002096. DOI: 10.1002/14651858.CD002096.pub2 
RIBEIRO, R.B.; MARTINS, H.S.; SANTOS, V.A.; EL KHOURI, M.; DUARTE, L.S.; BURATTINI, M.N.; CORDEIRO, Q.; CAMARGO, L.M.A. \& CORBETT, C.E.P. - Evaluation of Helicobacter pylori colonization by serologic test (IgG) and dyspepsia in volunteers from the countryside of Monte Negro, in the Brazilian Western Amazon region. Rev. Inst. Med. Trop. Sao Paulo, 52(4): 203-6, 2010

12. Nelson DB, Murdoch M, Sandozi IK, Dalmasso AP, Crabtree JE, Ho SB. Dyspepsia is associated with CagA-positive Helicobacter pylori. Am J Gastroenterol. 2000;95:3412-7.

13. Quigley EM, Keohane J. Dyspepsia. Curr Opin Gastroenterol. 2008;24:692-7.

14. Rehnberg-Laiho L, Rautelin H, Koskela P, Sarna S, Pukkala E, Aromaa A, et al. Decreasing prevalence of Helicobacter antibodies in Finland, with reference to the decreasing incidence of gastric cancer. Epidemiol Infect. 2001:126:37-42

15. Selgrad M, Kandulski A, Malfertheiner P. Dyspepsia and Helicobacter pylori. Dig Dis. $2008 ; 26 \cdot 210-4$
16. The Gastrointestinal Physiology Working Group of the Cayetano Heredia and the Johns Hopkins University. Ecology of Helicobacter pylori in Peru: infection rates in coastal, high altitude, and jungle communities. Gut. 1992;33:604-5.

17. Tindberg Y, Bengtsson C, Granath F, Blennow M, Nyrén O, Granström M. Helicobacter pylori infection in Swedish school children: lack of evidence of child-to-child transmission outside the family. Gastroenterology. 2001;121:310-6.

18. Vakil N. Dyspepsia, peptic ulcer, and H. pylori: a remembrance of things past. Am J Gastroenterol. 2010;105:572-4.

19. Van Zanten SJ. Treating non-ulcer dyspepsia and H. pylori. BMJ. 2000;321:648-9.

Received: 18 December 2009

Accepted: 10 June 2010 